\title{
Impact of climate change on phenology of Delonix regia (Bojer ex Hook.) Raf. across Mumbai
}

\author{
Farhan Suraliwala \& Bindu Gopalkrishnan* \\ Department of Botany, SVKM'S Mithibai College of Arts, Chauhan Institute of Science \& Amruthben Jivanal College of Commerce and \\ Economics, (Autonomous). Affiliated to University of Mumbai, Vile Parle (West), Mumbai 56, India \\ *Email: bindu_phd@rediffmail.com
}

\section{ARTICLE HISTORY}

Received: 08 May 2021

Accepted: 14 July 2021

Available online

Version 1: 24 August 2021

Version 2: 05 February 2022

KEYWORDS

Phenology

Delonix regia

Gulmohar

Mumbai

\section{ABSTRACT}

The average annual temperatures are gradually increasing over time since few decades. This has led to global warming and change in climate. The increase in temperature has not only affected the humans but the flora too. In many flowering plants the temperature has altered the phenology (timing) of flowering, example Cassia fistula, Samanea saman, Delonix regia etc. An attempt is made to investigate the tree Delonix regia (Bojer ex Hook.) Raf. commonly known as Gulmohar. It is monitored for its flowering time since 2016 to 2019. The area selected for study was Bhayandar, Mira road, Andheri and Vile Parle in Mumbai. The data obtained was further analyzed with the literature from different Flora's and research papers. The actual flowering time according to the old literature was April to June. Since few years it has been observed that Gulmohar flowered twice i.e. October to December and also April to June. The amount of flowers bloomed during October - December was scanty while mass bloom was witnessed during April to June. The phenology of flowering has shifted earlier in response to warming during October - December. The shift in the timing of flowering may have resulted in reproductive failure in the plant. This behaviour of plants is of great concern. More broadly it is important to mitigate climate change by controlling global warming in order to conserve the $D$. regia trees. It can be used as bio indicator stating the climate change in Mumbai.

\section{Introduction}

Our mother earth has experienced a constant climate change. It has not only affected mankind but also the flora and fauna. Plant phenology is strongly controlled by climate $(1-4)$. It has consequently become one of the most reliable bio indicators of ongoing climate change (5). In the past the phenology of several plants were recorded by various Botanical gardens, individual families and networks as an indicator of oncoming climate of a place. Mr. Robert Marsham the father of British Phenological recording has carried out many work in this field (6). Recently many countries are focusing on phenology of plant with respect to climate change. For example in Nigeria phenological study of Delonix regia (Bojer ex Hook.) Raf. was recorded (7). Studies on phenological response of plants to climate change in an urban environment is also done with respect to ecosystem (8). In Macao, 12 species of plants for its phenological changes under the effects of extreme climate was also reported (9). There are also studies related to plant phenology and distribution in relation to recent climate change (10). Researchers have worked on the change in phenology in ephemerals and its implications for pollination and fruit settings (11). In India, Rhododendron from eastern Himalaya was investigated with respect to change in flowering time (12). Thus, in India also plants have been used as an indicator for the arrival of various seasons. But due to climate change there is an increase in temperature during past several decades (13). This has affected the phenology (timing) of flowering, in many trees such as Cassia fistula, Samanea saman, D. regia etc. Current study is an attempt made to know the impact of climate change on the phenology of $D$. regia.

Delonix regia (Bojer ex Hook.) Raf. belongs to family Caesalpiniaceae and is commonly known as Gulmohar (14). It is a large deciduous street tree of India, native to Madagascar. The Gulmohar was discovered by Botanist Wensel Bojer in $19^{\text {th }}$ Century. It is a multipurpose tree planted on eroded sites for erosion control and for soil rehabilitation. Gulmohar is planted as avenue tree due to its huge canopy to provide shade and aesthetic beauty. In Bangladesh, the aboriginals used the leaves and flowers in curing diabetes. The large pods and wood is used as fuel. The seed contains gum that is used in textile, food

(C) Farhan \& Bindu (2021). This is an open-access article distributed under the terms of the Creative Commons Attribution License, which permits unrestricted use, distribution and reproduction in any medium, provided the original author and source are credited (https://creativecommons.org/licenses/by/4.0/). 
industries and also as a binder in the manufacture of tablets. Recent research on Gulmohar have shown many medicinal properties like antidiabetic, antiinflammatory, in gynaecological disorders etc. (15). Due to its economic and medicinal values the tree was investigated. According to the various literature and Flora it is evident that the tree flowered from April to May when the average temperature is $37{ }^{\circ} \mathrm{C}$ to $40{ }^{\circ} \mathrm{C}(16-18)$. Since few years as there is increase in temperature even in the month of October and the trees bloomed although not profusely. There was lot of changes observed within those flowering period. Thus, this shift of flowering in Gulmohar is of great concern with respect to the ecosystem.

\section{Materials and Methods}

\section{Study Locations}

The area selected for the study was Andheri, Vile Parle, Mira Road and Bhayandar in Mumbai, India. The average temperature recorded since four years are April to June $\left(\max 38.82{ }^{\circ} \mathrm{C}\right.$ to $32.43{ }^{\circ} \mathrm{C}$; $\min 27.36$ ${ }^{\circ} \mathrm{C}$ to $\left.25.33{ }^{\circ} \mathrm{C}\right)$ and October to December $\left(\max 35.84{ }^{\circ} \mathrm{C}\right.$ to $33.93{ }^{\circ} \mathrm{C}$; $\min 22.68{ }^{\circ} \mathrm{C}$ to $17.89{ }^{\circ} \mathrm{C}$ ). The meteorological data for 4 consecutive years was obtained from Regional Meteorological Centre, Mumbai (19).

\section{Methodology}

For the current study, the trees from the above mentioned locations were observed since the first blooming of flowers till the last ones. The flowering periods were compared with the various Flora since 1903 to 2005. The trees were monitored for its flowering and fruiting during both the occasion.

\section{Results and Discussion}

\section{Meteorological data}

The data was obtained from Regional Metrological Centre, Mumbai. It is represented in Table 1.

\section{Floristic record from Literature}

Various Flora were referred to check the flowering time of Delonix regia in the past. The details are given in Table 2.

\section{Phenological studies}

The data obtained from the phenological studies are represented in Table 3-6.

It was observed that $D$. regia flowered twice in a year i.e. from April-June and October -December over past few years. The tree flowered in Mumbai in the months of October and lasted till December to first week of January. The maximum temperature noted during the blooming period was ranging from $32{ }^{\circ} \mathrm{C}$ $35{ }^{\circ} \mathrm{C}$. The flowers bloomed and dwindled leading to no fruitification. Certain flower showed abnormal arrangement of petals. The size of the flowers was much smaller compared to the flowers which bloomed on the same tree during the month of April to June. The maximum temperature recorded during these years were $38.82{ }^{\circ} \mathrm{C}$ to $32.43{ }^{\circ} \mathrm{C}$. The colour of the flower were much lighter than the normal bloomed flowers. The Gulmohar tree when bloomed in October - December month, was fully covered with foliage whereas the tree was deciduous during the actual flowering season (Fig. 1, 2).

Table 1. Meteorological data stating average maximum and minimum temperature since 2016 -2019

\begin{tabular}{|c|c|c|}
\hline Year & $\begin{array}{c}\text { Max Temperature } \\
\left({ }^{\circ} \mathrm{C}\right)\end{array}$ & $\begin{array}{c}\text { Min Temperature } \\
\left({ }^{0} \mathrm{C}\right)\end{array}$ \\
\hline April 2016 & 33.69 & 24.18 \\
\hline April 2017 & 33.78 & 22.63 \\
\hline April 2018 & 33.75 & 23.73 \\
\hline April 2019 & 38.82 & 24.11 \\
\hline May 2016 & 34.35 & 27.36 \\
\hline May 2017 & 33.01 & 26.32 \\
\hline May 2018 & 34.29 & 26.48 \\
\hline May 2019 & 33.79 & 26.00 \\
\hline June 2016 & 32.91 & 26.77 \\
\hline June 2017 & 32.62 & 26.18 \\
\hline June 2018 & 32.53 & 25.33 \\
\hline June 2019 & 32.43 & 27.03 \\
\hline October 2016 & 32.20 & 22.68 \\
\hline October 2017 & 33.68 & 25.00 \\
\hline October 2018 & 35.84 & 23.52 \\
\hline October 2019 & 32.99 & 24.36 \\
\hline November 2016 & 34.79 & 18.74 \\
\hline November 2017 & 33.99 & 22.40 \\
\hline November 2018 & 35.30 & 21.83 \\
\hline November 2019 & 33.71 & 23.04 \\
\hline December 2016 & 33.93 & 17.89 \\
\hline December 2017 & 31.12 & 18.44 \\
\hline December 2018 & 32.37 & 18.14 \\
\hline December 2019 & 32.53 & 21.45 \\
\hline
\end{tabular}

Table 2. Comparison of Flowering time of $D$. regia (Bojer ex Hook.) Raf. tree with the different Flora

\begin{tabular}{clcl}
\hline $\begin{array}{c}\text { Sl. } \\
\text { No. }\end{array}$ & \multicolumn{1}{c}{ Flora } & Years & $\begin{array}{c}\text { Flowering } \\
\text { time }\end{array}$ \\
\hline 1 & Flora of Bombay Presidency & 1903 & April-June \\
\hline 2 & Flora of Maharashtra & 1998 & April-June \\
\hline 3 & BSI Flora of Maharashtra & 2001 & April - Sept \\
\hline 4 & $\begin{array}{l}\text { Flora of Sanjay Gandhi National Park } \\
\text { Borivali-Mumbai (Bombay) }\end{array}$ & 2005 March-June \\
\hline
\end{tabular}

While studying the phenology it was observed that the flowers were visited by pollinators during the month of April - June but none of the pollinators were seen during October - December. Detailed studies on the pollinators were not carried out. The literature survey revealed that the pollinators which visited $D$. regia were Lepidoptera and Hymenoptera members. The Lepidopterans include Papilio polytes, Graphium agamemnon, Pachliopta hector and Pachliopta aristolochiae (20). The flowers which bloomed in April - June produced fruit in the month of July which lasted for long time. The fruit setting was absent for the trees that bloomed in the month of October - December.

\section{Conclusion}

Delonix regia (Bojer ex Hook.) Raf. used to flower earlier in all over Mumbai from the month of April to June. This is also evident from the flowering time 
Table 3. Phenological observations of D. regia tree during the year 2016

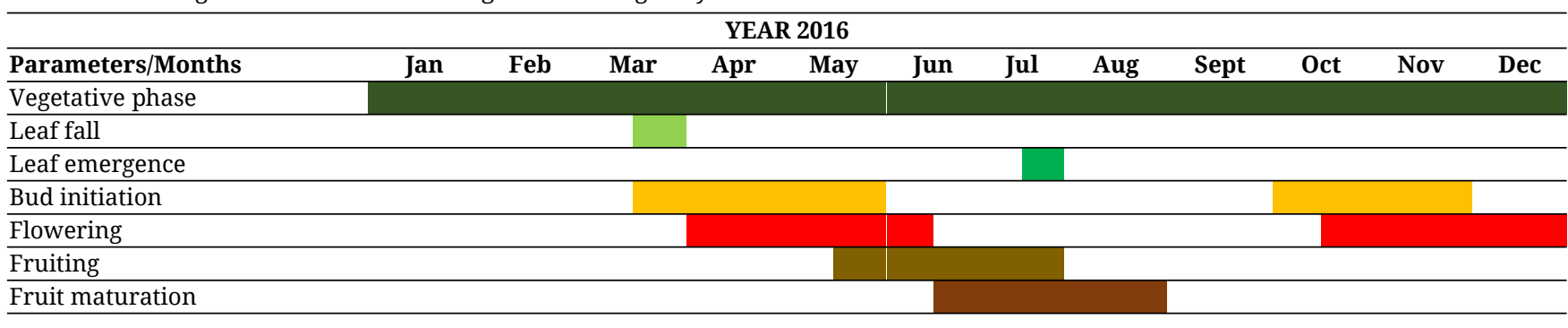

Table 4. Phenological observations of $D$. regia tree during the year 2017

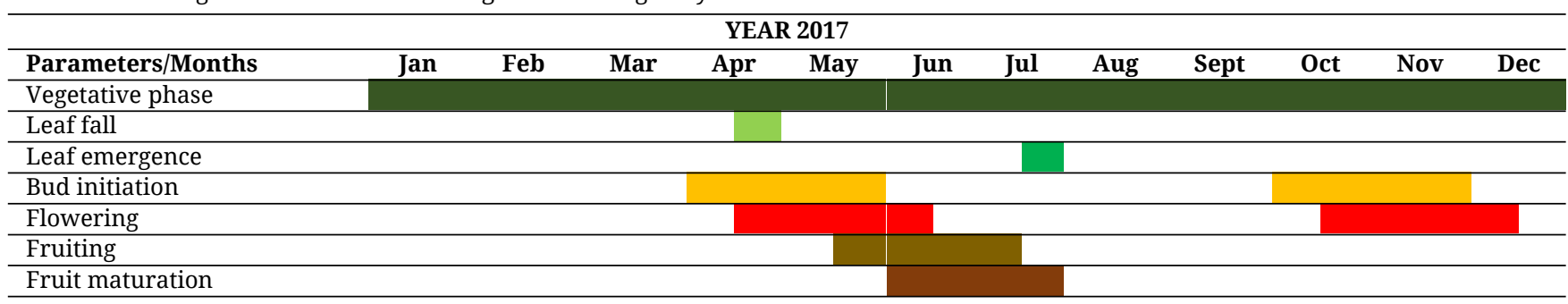

Table 5. Phenological observations of $D$. regia tree during the year 2018

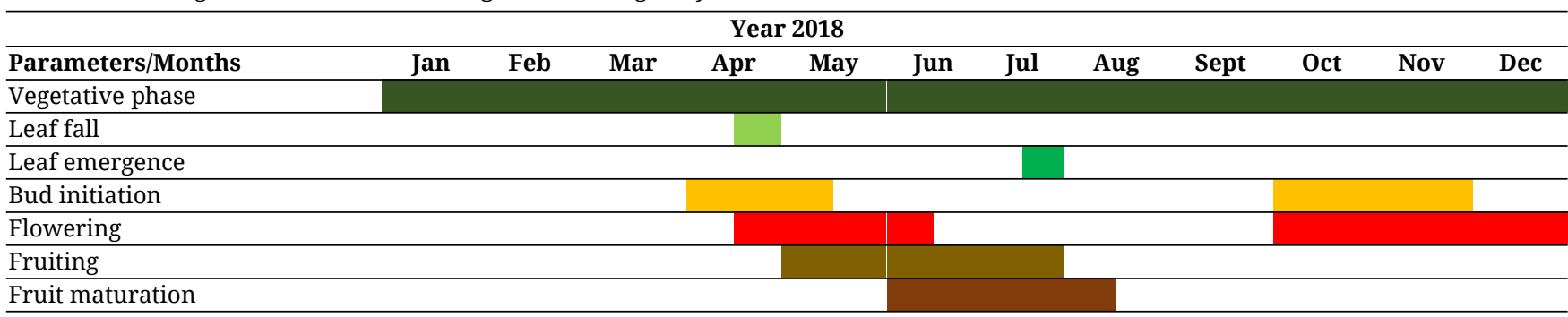

Table 6. Phenological observations of $D$. regia tree during the year 2019

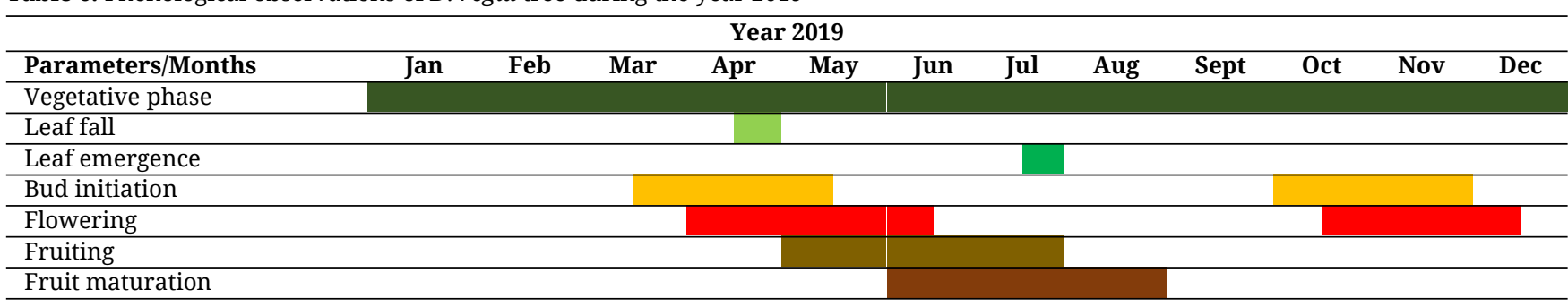

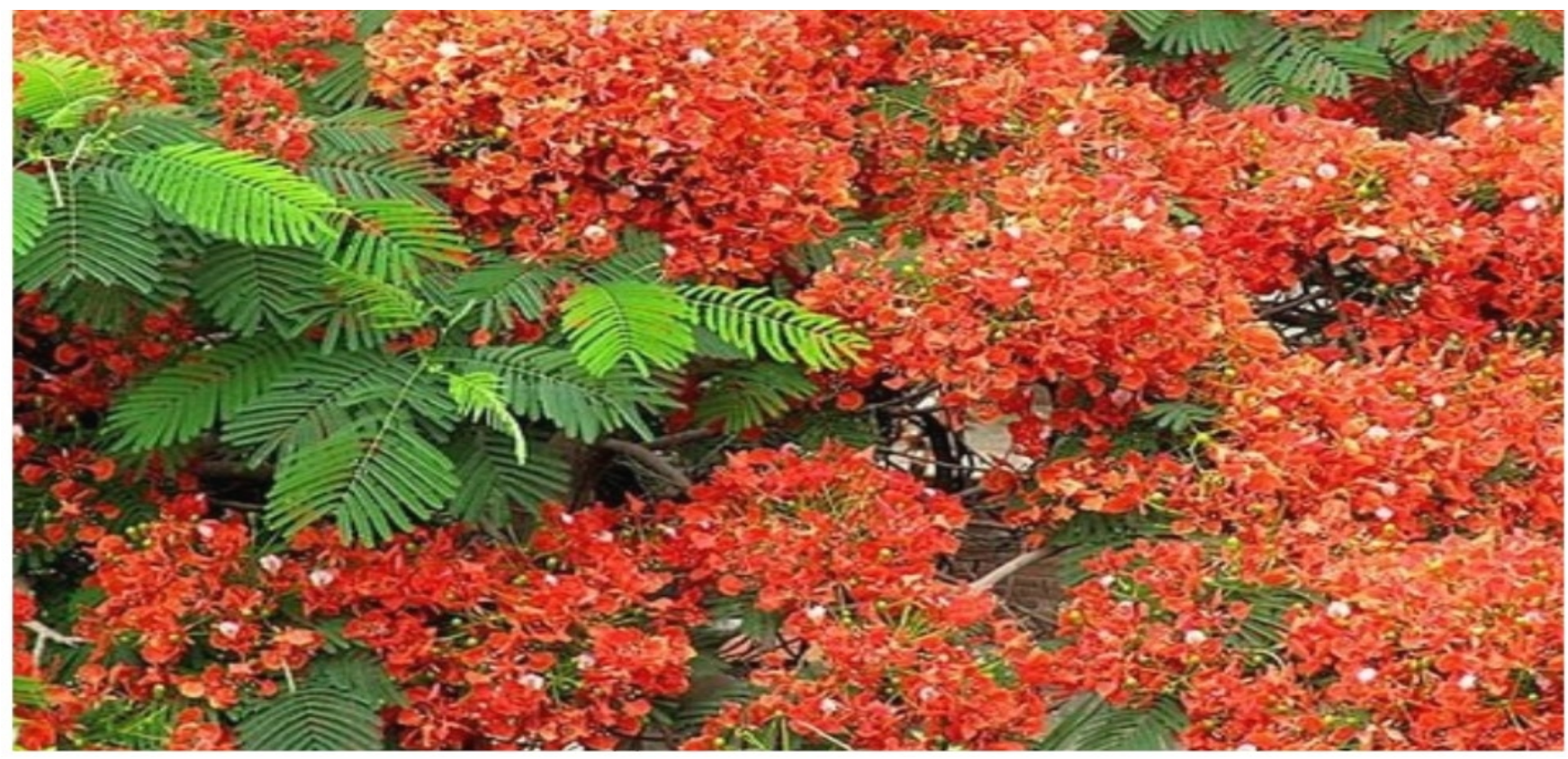

Fig. 1. D. regia with profuse flowering in the month of April. 


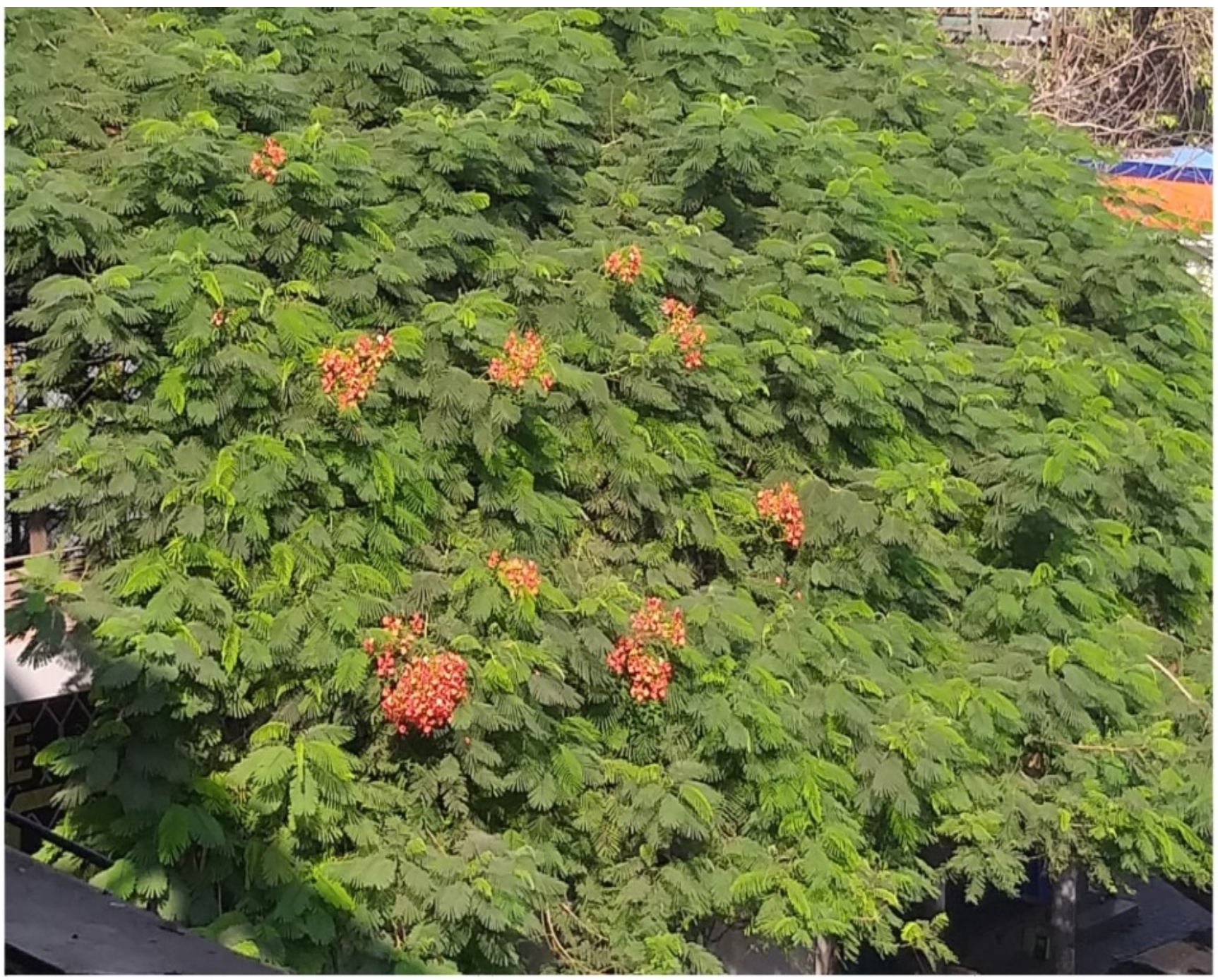

Fig. 2. D. regia with scanty flowering in the month of December.

mentioned in Flora of Bombay Presidency written in 1903 and Flora of Maharashtra 1998. As the year passed the flowering period also showed changes like in BSI Flora of Maharashtra published in 2000 a shift from April to September, Flora of Sanjay Gandhi National Park Borivali-Mumbai (Bombay, 2005) recorded the flowering time from March -June. It always flowered only once in a year. The current investigations at different sites in Mumbai recorded that, Gulmohar flowered twice a year i.e. in the month of April - June and also October - December. During the flowering period of October - December the tree did not produce any fruit. This reproductive failure in plant species may be due to absence of pollinators which is only present in the month of April - June. Changes in Gulmohar flowering period in Mumbai is a visible indicator of the significant increase in temperature. It also highlights the need of Mumbai to control the increase in temperature in order to maintain the ecological balance. It is a significant warning given by Gulmohar tree. Detailed studies of Gulmohar with regard to pollinators and edaphological aspects will be carried out in future.

\section{Acknowledgements}

The authors greatly acknowledge, the Regional Metrological Centre, Mumbai for providing the required data for the research work.

\section{Authors' contributions}

FS and BG both the authors have carried out the observations and collections of data in the field, wrote the full manuscript with critical analysis.

\section{Conflict of interests}

Authors do not have any conflict of interests to declare.

\section{References}

1. Camille Parmesan, Gerry Yohe. A globally coherent fingerprint of climate impact across natural systems. Nature. 2003;421:3742. https://doi.org/10.1038/nature01286

2. Jenet $\mathrm{S}$ Prevey. Climate change: flowering time may be shifting in surprising ways. Current Biology. 2020;303:112-14. https://doi.org/10.1016/j.cub.2019.12.009

3. Victoria L Scaven, Nicole E Rafferty. Physiological effect of climate warming on flowering plants and insect pollinators and potential consequences for their interactions. Current Zoology. 2013;59:41826. https://doi.org/10.1093/czoolo/59.3.418

4. Win Tun, Jinmi Yon, Jong - Seong Jeon, Gynheung. Influence of 
climate change on flowering time. Journal of Plant Biology. 2021;64:193-203. https://doi.org/10.1007/s12374-021-09300-x

5. Oscar Gardo, Juan Jose Sanz. Impact of climate change on plant phenology in Mediterranean ecosystem. Global change Biology. 2010;16:1082-1106. https://doi.org/10.1111/j.13652486.2009.02084.x

6. Fiona Tooke1, Nicholas H. Battey. Temperate flowering phenology. Journal of Experimental Botany. 2010;61:2853-62. https:// doi.org/10.1093/jxb/erq165

7. Echereme, Chidi B, Mbaekwe, Ebenezer I, Ekwealor, Kenneth U. Phenological Study of Flamboyant Tree (Delonix regia (Boj. ex Hook.) Raf.) Growing in Onitsha, Anambra State, Nigeria. International Journal of Scientific and Research Publications. 2015;5:91-94.

8. Zhongkui Luo, Osbert J. Sun, Quansheng Ge, Wenting Xu, Jingyun Zheng. Phenological responses of plants to climate change in an urban environment. Ecol Res. 2006;1-8.

9. Zhang J, Yi Q, Xing F. Rapid Shifts of peak flowering phenology in 12 Species under the effects of extreme climate events in Macao. Sci Rep. 2018;8:13950. https://doi.org/10.1038/s41598018-32209-4

10. Robert I Bertin. Plant phenology and distribution in relation to recent climate change. The journal of the Torrey Botanical Society. 2008;135:126-46. https://doi.org/10.3159/07-RP-035R.1

11. Zachariah J Gezon, David Winouye, Rebecca E Irwin. Phenological change in a spring ephemeral implications for pollination and plant reproduction. Glob. Chang Biol. 2016;22(6):1779-93 https://doi.org/10.1111/gcb.13209

12. Sailesh Ranjitkar, Eike Luede Ling, Krishna Kumar Shrestha, Kaiyun Guan, Jianchu Xu. Flowering phenology of tree Rhododendron along an elevation gradient in two sites in the Eastern Himalayas. Int J Biometeorol. Springer. 2012;57(2):225-40. https://doi.org/10.1007/s00484-012-0548-4

13. Shyam Vir Singh Chauhan, Seema Chauhan. Climate change and trends in phenology of Cassia fistula L. in Agra (India) -1965-2019. Journal of Native and Alien Plant Studies. 2020;16:23-31. https:// doi.org/10.37555/2707-3114.16.2020.219808
14. Almeida MR. Flora of Maharashtra, Mumbai: Orient Press; 1998. p.191.

15. Nidhi Suhane, Rishi Raj Shrivastava, Mahendra Singh. Gulmohar an ornamental plant with medicinal uses. Journal of Pharmacognosy and Phytochemistry. 2016; 5(6):245-48.

16. Sharma BD, Singh NR. Flora of Sanjay Gandhi National Park Borivali-Mumbai (Bombay), BSI Ministry of Environment and Forests; 2005. p. 248.

17. Singh NP, Karthikeyan S. Flora of Maharashtra State (Dicotyledons), BSI; 2000. p. 803.

18. Theodore Cooke. Flora of the Presidency of Bombay, BSI Calcutta; 1903. p. 415.

19. http://www.imdmumbai.gov.in/scripts/search.asp

20. Chandar Sujan G, Atluri. J B. Pollinators and its behaviour on Delonix regia (Boj. ex Hook.) Raf. (Family: Caesalpiniaceae). IOSR Journal of Environmental Science, Toxicology and Food Technology. 2016;10(4):27-34.

\section{Additional information}

Peer review information: Plant Science Today thanks Sectional Editor and the other anonymous reviewers for their contribution to the peer review of this work.

Reprints and permissions information is available at https://horizonepublishing.com/journals/index.php/PST/open_access_policy

Publisher's Note: Horizon e-Publishing Group remains neutral with regard to jurisdictional claims in published maps and institutional affiliations.

To cite this article: Farhan S, Bindu G. Impact of climate change on phenology of Delonix regia (Bojer ex Hook.) Raf. across Mumbai. Plant Science Today. 2021;8(4):1070-1074. https://doi.org/10.14719/pst.2021.8.4.1253

Plant Science Today, published by Horizon e-Publishing Group, is covered by Scopus, Web of Science, BIOSIS Previews, Clarivate Analytics, etc. See https://horizonepublishing.com/journals/index.php/PST/indexing_abstracting 